\title{
The walk-and-talk methodology - researching place and people
}

\author{
Maruta Pranka \\ Rīga Stradiņš University, Riga, Latvia \\ University of Latvia, Riga, Latvia
}

\begin{abstract}
The article focuses on walk-and-talk interviews, which are yet a little-used research method in Latvia. The term is used in the social sciences and humanities and is an appropriate method for gathering data in order to determine the relationship of an individual or a social group with a specific place. The method in a pilot project was used to listen to life experiences in Tūja, a village along the Baltic coast in Latvia. The study focused on social change in Tüja and the influence of the economic and political changes of the 1990s on the living conditions and lifestyle of the local inhabitants. The pilot project was conducted by the researchers from the Institute of Philosophy and Sociology of University of Latvia.
\end{abstract}

\section{Introduction}

Living space, or place, is a form of both physical and mental existence. A space experiences historical change, while at the same time changing our own relationship with the space. We can be free in a space, but it can also limit us. It is impossible to judge the space around us and the place where we are located as isolated from the past events associated with them - each place in a story is linked both - to an event and the chronological boundaries of this event. Therefore, places mentioned in life stories - whether event locations, projected locations or merely episodic locations - are recorded along with time [1].

Places are dynamic, contested and complex social phenomena created by the particular interaction of flows and processes such as social relationships, economics and politics operating at varying levels from the "local" to the "global" [2].

An individual's forms of relationship with their environment, the space around them, and specific places are studied in the social sciences in several different ways: through observation, but also through qualitative and quantitative individual interviews. One of the methods of study in this field is called the "walk-and-talk interview", a term that is used in the social sciences and humanities and which is an appropriate method for gathering data in order to determine the relationship of an individual or social group with a specific place. It is also called the "go-along" method, which is essentially a hybrid of interviewing and participant observation, with the researcher accompanying informants as they go about their daily routines and asking them questions along the way [3]. Thus, the context of the current or past daily life of an individual is studied.

This article focuses on walk-and-talk interviews, which are so far a little-used research method in Latvia. The researchers from the Institute of Philosophy and Sociology of Latvia University applied this method in a pilot project whose aim was to listen to life experiences in Tūja, a village along the Baltic coast in the Vidzeme region of Latvia. The study focused on social change in Tüja and the influence of the economic and political changes of the 1990s on 
the living conditions and lifestyle of the local inhabitants. The researchers were also interested in the ethnic makeup of the local population, the conditions that have led to that makeup and the relationship between people of different ethnic groups in the village. The pilot project was conceived as a one-day expedition to Tüja involving three researchers and a filming group.

The goal of this article is to analyse the methodological experience gained during the fieldwork part of this project.

\section{Methodology}

Exploring different aspects of life while in motion is nothing new. In anthropology, various types of observation are used to collect data while studying individuals, when they move around at various spatial levels within the context of their daily lives rather than separated from it. It is a research method that connects a person's narrative with the place, with the space where it is narrated.

Alex Mahoudeau refers to Beaud's experience in ethnographic research, which confirms that an in-depth interview only takes its actual meaning in "context", vis-à-vis the place and time of the interview. The situation of observation is, in and of itself, a situation of observation; more accurately, only the observation of the social setup (people and places) that makes up the interview provides the elements for its interpretation [4].

The walk-and-talk method focuses on the relationship between what people say and where they say it. The content of this type of interview is significantly influenced by the landscape, environment and place where the interview takes place. According to Penelope Kinney, studies exploring the needs of people in regard to town planning, the links between identity and community, transitions and the community, and how place influences people's roles could all potentially benefit from the use of walking interviews [5].

Walk-and-talk can be realised in various different forms, but an essential precondition of them is that the researcher conducts the interview while in motion in a specific environment, space, place and time.

Richard Carpiano believes that the respondent should choose the route, or informant, who is the expert and guide through the environment. The key is that the participants make all the decisions, including the route, the length of the walking interview, as well as what they would like to show the researcher. The participants are in control of the interview; they are regarded as experts in their geographical area and act as tour guides [6]. Adam Reed, for his part, turns our attention to studies in which the interviewer selects the route [7]. Of a similar mind are Nick Emmel and Andrew Clark, who have developed and supplemented this research method and believe that the researcher must become the guide. This does not mean that there must be strict guidelines for directing the interview, but it should progress towards the topics the researcher wishes to study [8]. The leading role in each specific study, however, is also determined by whether the neighbourhood expert is the interviewer or the interviewee.

The advantages of this research method include the fact that the interviewee gives the researcher the opportunity to see him or her interact with other participants during the interview; the interviewees, involved in the process, may also feel more confident in a familiar environment. Various authors have praised the advantages of the walk-and-talk method, emphasising that walking interviews also provide insights into the relationships with others or the sense of alienation or loneliness that the participant experiences; such insights are less obvious in sit-down interviews [9]. The walking interview provides the researcher with an opportunity to observe and not just hear an account [10].

Walking alongside a participant is regarded as an inclusive process compared with the traditional sit-down interview, because it is viewed as more of a partnership, thus reducing 
power imbalances. It allows participants to feel more comfortable with the research because it is being conducted in a geographical location that they are familiar with [11].

However, there are also a number of significant risks related with the walk-and-talk interview method. They are beyond the powers of the researcher to influence and that may affect the progress and quality of the study. First, the aspect of confidentiality, because the interview takes place in a public space, where others can observe them. However, this aspect can also have a positive effect on the interview if the study format allows for additional participants (respondents) to join the research process. In the study at hand, the fact that additional respondents joined the interview/walk contributed important information to the study. Nevertheless, it is impossible to ensure the anonymity of the study participants in such a way as can be achieved in traditional interviews.

A second very important factor is inclement weather, which can disturb or halt the data collection process.

Third, sometimes places or environmental objects cannot be reached due to poor road conditions, physical barriers or other factors. We encountered such an obstacle during our study as well.

Fourth, both respondents and researchers may be physically unable to participate in longer walks or reach distant destinations due to the lack of time or physical condition.

\section{Description of the research site}

Tūja is a settled area in Liepupe administrative parish in Salacgrīva region. It is located on the shores of the Gulf of Riga, 33 kilometres from Salacgrivva and 75 kilometres from Riga.

Several unique sites can still be found in the centre of Tūja, such as the abandoned buildings of the old brick factory and the Soviet-era housing constructed nearby for the factory's employees. Many former factory workers still live in these houses. There was once also a fish processing business in Tüja, which the locals called the "fish point". Only a few large chimneys remain of the brick factory Tüja was famous for in the interwar era. The factory produced high-quality bricks, which were used for the facade of the Powder Tower in central Riga. The Moscow Kremlin, damaged during the Second World War, was also reconstructed using bricks from Tūja. The brick factory operated until 1991, and it was here where scenes from the classic Latvian film Ceplis (dir. Rolands Kalniņš, 1972, Rīgas Kinostudija) were filmed.

Nowadays, only the ruins of the factory remain, defining the centre of Tūja as one heads towards the sea. But Tüja also presents a very different face, having in recent years become an exclusive vacation and recreation destination with many expensive private residences.

\section{Organisational aspects and progress of the study}

The researchers chose the site of Tūja, because anthropology professor Vieda Skultāne, who was a participant in the project, has lived in the village for many years. She knows local residents of the older generation and is a regular visitor to the local library, which serves as the main cultural and information centre in the village. The research project, led by Skultāne, focused on the diverse experiences of different ethnic groups in Latvia. The red brick chimneys in central Tūja as well as the significant proportion of Russian residents living in the brick factory's apartment buildings led the researchers to apply the walk-and-talk method to the study.

During the preparation stage of the pilot project we performed some preliminary work. For instance, a week before the project began, an announcement was posted in central Tūja that invited local residents to participate in a stroll around the village and share their memories 
with researchers from the University of Latvia. The invitation was intended to reach as wide an audience as possible, with the goal of gathering as much information and detail as possible as the conversations stimulated people's memories.

In this particular study, the walk-and-talk methodology allowed the researchers to reach out to participants who may have otherwise been somewhat reserved, in other words, the Russian population of Tūja who moved to Latvia immediately after the Second World War in response to job offers there. As previous research experience has shown, interviews conducted in the Latvian language also led to more limited responses from the latter group. In this study, the stroll through the former brick factory involved both Latvians and members of the so-called Russian-speaking community, and both Russian and Latvian were used in communicating.

The meeting point was at the café in the centre of the village. Three women and one man arrived - all of them retired former employees of the brick factory. Three interviewers (researchers) and a filming group conducted the interviews. Each researcher had their own task: one observed and unobtrusively guided the group's movement, also ensuring that the interviewees remained visible to the camera at all times. Other led the conversation and recorded it on a voice recorder; the third followed the conversation closely, posed supplemental questions and potentially involved people in the conversation who joined the stroll along the way. Some researchers emphasise that filming and audio recording can hinder an interview or distract an interviewee [12]. However, with the consent of the respondents, we filmed and made an audio recording (using a video camera with an external microphone as well as a voice recorder as a backup) of the walk-and-talk interview in Tūja. Our purpose was to fully record the course of the interview and the information obtained. Two professional video and audio sound engineers took part in the study.

Despite the fact that there were several speakers, and sometimes two people spoke at the same time, interrupting each other, the resulting video recording reflects everything that each of the participants said during the conversation. The video recording has documentary value, because it chronicles the memories of specific people at a specific time and place. By signing a previously prepared form, the participants of the walk-and-talk interview confirmed that they had no objections to being filmed and that their narratives would be used for research purposes.

The walk-and-talk method involved people in a joint event in which we, the researchers, showed respect for an important part of the interviewees' past. Specific places, the still visible layout of the rooms in the ruins of the former factory, the remains of the conveyor belt - all of these stimulated memories and encouraged the participants in the walk to open up and become witnesses to their own pasts. The researchers could observe how spaces and locations are involved in and stimulate the memory process. In addition, there was active communication between the interviewees themselves, who sometimes presented different version of the same events, all stimulated by the place, time and the walk itself.

The study anticipated that additional participants might unexpectedly join the walk. As the group walked through Tüja, about forty years old man joined the group and supplemented - but also sometimes disagreed with - what the original participants narrated. Thanks to him, the experience in Tüja gained an additional perspective, a perspective that was not related to the brick factory, but to the more distant history of this settled area. As the walk continued, a family joined us as well, expanding the original walking route and leading it toward the sea. There, freshly painted and still in good condition, stood the oldest building of Tüja. It was located close to the shore and dated to the $17^{\text {th }}$ century. The young owner of the building told the group about the building's history, a story that had, like the building itself, been handed down from generation to generation within the same family. Thus, the researchers gained an even deeper insight into the history of this place, of which 
the initially selected object of interest - the brick factory - was simply one episode. The experience also proved that a private building in the hands of caring owners can be preserved for centuries while a socially significant public building - the brick factory - may cease to function following repeated changes in directors and responsible state institutions as well as new economic circumstances, thus falling into ruin. Despite the fact that the factory ruins were now in private hands, as the researchers learned during the walk through Tūja.

\section{Results - themes in the narratives}

The most significant themes in the narratives were linked with the history of Tüja as a settled area as well as Tūja in the present day. The brick factory played the "main role" in the narratives of the former employees as they spoke about their work lives. As they walked around and through the various areas of the factory, they told about their work, the content of their work, the operations of the brick factory and its closing. As they described the former factory and surrounding area, the respondents accented the current degradation of the environment. Interspersed between stories about work was information about the respondents' daily lives, lifestyles, interpersonal relationships, specific events, former colleagues, business directors, private life, the Soviet era and the restoration of Latvian independence. "All that's left here now are senior citizens and drunks," said B. when reflecting on the changes in the local population.

The respondents told about the migration processes during and after the Second World War, when labour for Latvian industry was recruited from war-torn regions of Russia and Belarus. Most of the workers at the Tūja brick factory came from these regions, while the local population was mostly employed in the fish processing industry. In her narrative, the former factory employee B. told how both the German and Soviet military forces forced local residents to relocate within the territories they occupied: "As is usual in wartime, residents were chased around almost like herds of cattle. There was no choice. Both the Germans and our own people, the Russians, relocated us and chased us around. In Pskov, everything was utterly destroyed, down to the ground." After the war, B. visited her native land but was unable to even locate the ruins of the house where she was born.

As mentioned above, a younger woman named A. joined the walk later, during the course of the walk-and-talk interview, and her narrative shifted the focus in a new direction, away from the brick factory. She told about the house on the Baltic coast that she had inherited from her grandparents. Her ancestors had inhabited it since the $17^{\text {th }}$ century. She mentioned specific events and dates that intertwined with the memory narratives of older generations. A.'s own narrative, for its part, was supplemented by a story from the retired factory workers about the transporting of bricks right past A.'s house to the sea: "A narrow-gauge railway led from the factory to the port, and the bricks were transported on little train cars. Big barges would moor in the port, upon which 30,000 to 40,000 bricks would be loaded, sometimes even 70,000 bricks. Tugboats would then pull the barges to Riga. But the port didn't operate for very long, only until about 1953".

\section{Conclusions}

During the one-day pilot project, the walk-and-talk method resulted in diverse informational material regarding people's relationships with a specific place - namely, Tūja - and the effect that political and social changes have had on this place and the relationships between local residents.

Of course, the choice of the method depends on the goals and tasks of the study. If the goal of a study were to collect life-story narratives in general, then the traditional manner of 
interviewing would be more appropriate than the walk-and-talk method. In this case, however, we wished to examine the role of the brick factory in the history of this specific place and in the lives of the people living there; for this purpose, a group interview during a walk around the area proved stimulating and provided a diverse insight into the object of study.

This particular pilot project confirmed the researchers' hypothesis that walk-and-talk interviews are suitable for the collection of data regarding the perception of place and space. Such information tends to receive less attention in individual autobiographical interviews, but it highlights an individual's relationship with a specific place, space and environment. That was also the focus of our interest in this study.

Walk-and-talk interviews proved to be a very good research tool for studying the relationship between the individual and the community.

Regarding the risk factors associated with walk-and-talk interviews noted in the experience of other studies, we encountered two such factors during our project:

- We experienced an unexpected physical difficulty in reaching the specific site. The former brick factory in Tūja (more precisely, the ruins thereof) was under new ownership, and our walk was interrupted by the arrival of security guards, which hindered the further exploration of the area.

- Poor weather conditions. Because the pilot project took place in late autumn, the weather was cool, rainy and windy.

Because this pilot project was small in scale and the experience tested and gained therein was limited, we could not make comprehensive conclusions about all of the methodological aspects. The project also raised a number of questions that still need to be answered, for example, whether a walk-and-talk interview should be conducted only once or in several instalments, and whether individual interviews would be more productive than interviews simultaneously involving more participants, who then engage in discussions with each other. However, the things we heard in this pilot project, the themes that were raised and the former colleagues who were mentioned during the course of the walk encouraged us to continue the study with traditional life-story interviews with several individuals in their homes. Thus the researchers received a large amount of material, the findings from which were used in the "Ethnic and narrative diversity in life story constructions in Latvia" study [13]. We have concluded that mobile interviews can contribute important information to studies of the interaction between individuals and places as well as between communities and places.

We wish to thank:

1. Vieda Skultans-Shelley for the initial idea and methodological management of the pilot project.

2. Māra Zirnite for managing the organisational aspects of the pilot project.

3. The respondents - the residents of Tūja - who shared their life experience with us.

This article was written within the framework of the Memory Transfer between Generations: A Narrative Perspective fundamental and applied research project No. lzp-2018/1-0458 of the Latvian Council of Science and the Critical Thinking, Innovation, Competitiveness and Globalisation project of the University of Latvia (AAP2016/B033).

\section{References}

[1] I. Garda-Rozenberga, TRAMES 23(73/68), 2: 145-157 (2019)

[2] D. Massey, Marxism Today 6, 24-29 (1991). Retrieved from: http://www . aughty.org/pdf/global_sense_place.pdf 
[3] M. Kusenbach, Ethnography 4(3), 455-485 (2003)

[4] A. Mahoudeau, The walking interviews: some remarks on talking and walking, The Cobble And The Frame, Sociology of mobilisations and geographical imagination (2017). Retrieved from: https://tcatf .hypotheses . org/281

[5] P. Kinney, Walking Interviews. Social Research Update (University of Surrey, UK, 2017). Retrieved from: http://sru.soc . surrey . ac.uk/SRU67 . pdf

[6] R.M. Carpiano, Health Place 15(1), 263-72 (2009)

[7] A. Reed, J. Royal Anthropol. Institute 8(1), 127-141 (2002)

[8] N. Emmel, A. Clark, NCRM Working Paper Ser. 06/09 (2009). Retrieved from: http://eprints.ncrm.ac.uk/800/

[9] M. Butler, S. Derrett, Internet J. Allied Health Sci. Pract. 12(3), (2014). Retrieved from: https://nsuworks.nova.edu/cgi/viewcontent. cgi?article=1491\&context $=i$ jahsp\&httpsredir=1\&referer $=$

[10] P. Jones, G. Bunce, J. Evans, J.H. Gibbs, H.J. Rickets Hein,J. Res. Pract. 4(2), Article D2, (2008). Retrieved from: http://jrp.icaap.org/index.php/jrp/ article/view/150/161

[11] E.-M. Trell, B. van Hoven, Fennia - Int. J. Geography 188(1), 91-104 (2010). Retrieved from https://fennia.journal.fi/article/view/2522

[12] J. Evans, P. Jones, Appl. Geogr. 31(2), 849-858 (2011)

[13] V. Skultāne (ed.), Piederēt un atšksirties: romu, krievu un latviešu dzīvesstāsti Latvijā, LU FSU: Latvijas mutvārdu vēstures pētnieku asociācija "Dzīvesstāsts" (2017) 